\title{
Prevalence and characterization of Shiga toxin 0157 and non-0157 enterohemorrhagic Escherichia coli isolated from different sources in Ismailia, Egypt
}

\author{
Sahar M. EL-Alfy ${ }^{1}$, Salwa F. Ahmed ${ }^{2^{\star}}$, Samy A. Selim ${ }^{1}$, Mohamed H. Abdel Aziz ${ }^{1}$, \\ Amira M. Zakaria ${ }^{3^{*}}$ and John D. Klena ${ }^{4}$ \\ ${ }^{1}$ Microbiology Section, Botany Department, Faculty of Sciences, Suez Canal University, Ismailia, Egypt. \\ ${ }^{2}$ U.S. Naval Medical Research Unit No.3 (NAMRU - 3), Cairo, Egypt. \\ ${ }^{3}$ Biotechnology Institute, Suez Canal University, Ismailia, Egypt. \\ ${ }^{4}$ United States Centers for Disease Control and Prevention, China Office, Beijing, People's Republic of China.
}

Accepted 3 May, 2013

\begin{abstract}
Shiga toxin producing Escherichia coli (STEC) is recognized as important food borne pathogen, responsible for sporadic cases of serious outbreaks worldwide. The morbidity and mortality associated with several recent outbreaks due to STEC have highlighted the threat this organism poses to public health. This study was conducted to identify and characterize the virulence traits and antibiotic resistance of enterohaemorrhagic $E$. coli from different sources, between September 2008 and October 2009. A total of 384 samples from human, animal and environmental sources were collected from different locations in Ismailia, Egypt. $E$. coli isolates $(n=283)$ were identified by conventional microbiology culture and were phenotypically characterized using biochemical and motility tests. Multiplex PCR (mPCR) was applied for the detection of virulence genes (stx1, stx2, eaeA and EHEC $h / y A)$. From the overall number of $E$. coli isolates, $31.4 \%(89 / 283)$ were isolated from stools of humans with diarrhea, $17.3 \%$ (49/283) from stools of sheep, cattle and chicken with diarrhea, $16.6 \%(47 / 283)$ from urine of humans with urinary tract infection, $17.3 \%$ (49/283) from water, $6.4 \%$ (18/283) from sea-food, $6 \%$ $(17 / 283)$ from processed meat products, $3.9 \%(11 / 283)$ from dairy products and $1.1 \%(3 / 283)$ from poultry products (liver). The antibiotic resistance patterns showed that the isolates carried multi-drug resistance (MDR) phenotype to at least four antibiotics belonging to different classes: Erythromycin (E), gentamicin (CN), cefazolin (CZ), thiampinicol (TP), vancomycin (VA), ciprofloxacin (CIP) and ampicillin (AM). Shiga toxin genes were identified in 10 (3.5\%) suspected Enterohaemorrhagic $E$. coli isolates by mPCR. Serotyping of these 10 isolates demonstrated five different serogroups $(0157,0158,0114,0125$ and 026): three human isolates (serogroups 0157, 0158), four animal isolates (serogroups 0114, 026), two isolates from meat products (serogroups 0125, 0158) and one isolate from water (serogroup 0114). This study identified STEC 0157 from human cases with diarrhea, and demonstrated that meats and water could be contaminated with more than one STEC serotype. This is a concern due to their potential to cause human infections.
\end{abstract}

Key words: Hemorrhagic Escherichia coli, Shiga toxin, non-O157, O157, diarrhea, food, Egypt.

\section{INTRODUCTION}

Shiga toxin producing Escherichia coli (STEC) is the most important recently emerged group of foodborne pathogens (Abong'o et al., 2009). It can cause severe gastrointestinal disease, including fatal infections, and is 
being detected with increasing frequency worldwide. Transmission occurs usually through consumption of undercooked meat, unpasteurized dairy products and vegetables or water contaminated by faeces of carriers (Dunn et al., 2004) primarily because Shiga toxin-producing $E$. coli (STEC) is found to be part of the normal intestinal flora of animals (Ezawa et al., 2004). Person-toperson transmission has also been documented (Karmali, 1989; Paton and Paton, 1998). Although several investigations have been carried out in the laboratory to detect these organisms in recent years, this group remains one of the most difficult to detect. STEC strains do not only produce potent cytotoxins (verotoxins) but have also acquired the ability to adhere to the intestinal mucosa in an intimate fashion (O'Brien and Holmes, 1987; Hoffman 1993; Bettelheim, 1996). All STEC strains produce STEC-specific, plasmid-mediated hemolysin encoded by hlyA gene (Schmidt et al., 1994) and at least one Shigalike toxin (encoded by $s t x 1$ or stx2) (O'Brien and Holmes, 1987). Many produce intimin, a $97-\mathrm{kDa}$ attachment- and effacement protein, that is encoded by eae $A$ gene (Louie et al., 1993). The present study was aimed at investigating the prevalence of shiga-toxin producing E.coli strains from different human and environmental sources in one of the governorates in Egypt. The virulence characterisitcs and antimicrobial susceptibility of isolates were also studied.

\section{MATERIALS AND METHODS}

\section{Sample collection}

A total of 384 samples were collected from different sources in Ismailia governorate from September 2008 through October 2009. Sampling included various types of food, water, stool from diarrheal human and animal cases, and urine from patients with urinary tract infection (UTI).

A total of 99 food samples were randomly collected in sterile plastic bags from different local markets. The collected foods included meat products, poultry products, sea-food products and dairy products. Twenty five grams of each sample was treated with 225 $\mathrm{ml}$ of modified tryptic soy broth (mTSB- DifcoLa Jolla, CA/USA) and incubated with agitation (120 rpm) for $24 \mathrm{~h}$ at $37^{\circ} \mathrm{C}$ as described by Cowan (1985) and Ethelberg (2009). After enrichment for $24 \mathrm{~h}$ at $37^{\circ} \mathrm{C}$, aliquots of $100 \mu \mathrm{l}$ were plated onto Eosin Methylene Blue (EMB-Difco) agar to presumptively identify isolates as Gramnegative enteric bacteria and presumptive $E$. coli (green-metallic colonies), and onto Sorbitol MacConkey agar (SMAC-Difco) to test for sorbitol non-fermenting bacteria (colorless colonies). After 18 to $24 \mathrm{~h}$ at $37^{\circ} \mathrm{C}$, characteristic colonies from EMB agar and SMAC agar were transferred onto Tryptic Soy agar (TSA, Difco) and used for biochemical identification tests. Thirty one water samples were collected from the Ismailia freshwater canal and examined according to standard methods (APHA, 1998) isolates yielding typical green metallic colonies were inoculated into SMAC agar and incubated at $37^{\circ} \mathrm{C}$ for $24 \mathrm{~h}$ (APHA, 1998).

Fecal specimens $(n=179)$ were collected following standard fecal specimens $(n=179)$ were collected following standard methods
(CDC, 1997, 2007). Stool specimens were collected at early stages enteric illness from patients with diarrhea before initiating antibiotic therapy. Fresh stool sample, or a rectal swab was collected using a sterile rectal swab and inoculated into Tryptic soy broth (TSBDifco) transport medium (CDC, 2007). Within $2 \mathrm{~h}$ of specimen collection, samples were streaked onto SMAC agar plates supplemented with $0.05 \mathrm{mg} / \mathrm{L}$ Cefexime in order to examine the ability of the isolates to ferment sorbitol. After $24 \mathrm{~h}$ at $37^{\circ} \mathrm{C}$, plates were examined and individual $E$. coli-like colorless colonies were selected and subjected to further identification using standard biochemical procedures (Cowan, 1985).

Urine specimens were collected from the midstream urine (MSU) of symptomatic cases with urinary tract infection $(n=76 ; 24$ from males and 52 from females). Within two hours after collection, all urine samples were examined following standard procedures (Izenberg, 2003). Urine specimens were diluted with $5 \%$ saline solution, and $100 \mu \mathrm{l}$ from each diluted sample was directly used to inoculate EMB agar plates using sterile $10 \mu \mathrm{l}$ culture loops. Bacterial colonies grown were re-streaked onto Cefexime SMAC plates, and incubated for $24 \mathrm{~h}$ at $37^{\circ} \mathrm{C}$.

\section{Identification and biochemical characterization of isolates}

Purified suspected $E$. coli-like colonies $(\mathrm{n}=283$ ) were identified by examining the morphology and biochemical properties of growing colonies. Gram staining was evaluated following the procedure described by Merchant and Packer (1967) and E. coli-like colonies were subjected to different biochemical tests, including sugar fermentation tests, indole production test, Methyl-Red and VogesProskauer (IMIVC) tests, following the standard methods described by Cowan (1985).

\section{Antibiotic susceptibility tests}

The whole number of $E$. coli isolates $(n=283$ ) were tested for their susceptibility to 16 antibiotics listed in Table 1 . Testing was performed on Mueller-Hinton Agar plates using the Kirby-Bauer disk diffusion technique (Jorgensen et al., 1997). The antibiotic resistance of each $E$. coli isolate was determined based on the breakpoints of the inhibition zone diameters for individual antibiotic agents and as recommended by the disk manufacturer. The results were interpreted according to the guidelines of the Clinical Laboratory Standards Institute for antimicrobial susceptibility testing (CLSI, 2010).

Resistance to more than four antibiotics was as multidrug resistance (MDR). MDR index (MDRI) of individual isolates was calculated by dividing the number of antibiotics to which the isolate was resistant by the total number of antibiotics to which the isolate was exposed (Chandran et al 2008). Isolates with MDRI values of more than 0.2 or $20 \%$ were considered highly resistant.

\section{Congo red (CR) binding activity}

The individual $E$. coli isolates were tested for their binding activity with Congo red dye, which is an indicator of intestinal invasion (Berkhoff and Vinal, 1986; Koneman et al., 1999; Panigarhy and Yushen, 1990). Individual E. coli colonies were cultured onto Congo red medium and incubated at $37^{\circ} \mathrm{C}$ for $24 \mathrm{~h}$. Culture plates were then transferred at room temperature for additional $24 \mathrm{~h}$ of incubition. Growth of red colonies indicates a Congo red positive $(\mathrm{CR}+)$ 
Table 1. Antibiotic Resistance profile of $E$. coli $(\mathrm{n}=283)$ from different sources.

\begin{tabular}{|c|c|c|c|c|c|c|c|c|c|c|}
\hline \multirow{3}{*}{$\begin{array}{l}\text { Antibiotic agent } \\
\text { Number of isolates/Percentage }\end{array}$} & \multicolumn{10}{|c|}{ Resistance pattern } \\
\hline & \multirow{2}{*}{$\mathbf{N}$} & \multirow{2}{*}{$\%$} & \multirow{2}{*}{$\begin{array}{c}\text { Surface water } \\
49(17.3 \%) \\
\end{array}$} & \multirow{2}{*}{$\begin{array}{c}\text { Human stool } \\
89(31 \%) \\
\end{array}$} & \multirow{2}{*}{$\begin{array}{c}\text { Animal stool } \\
49(17.3 \%) \\
\end{array}$} & \multirow{2}{*}{$\begin{array}{c}\text { UTI } \\
47(16.5 \%)\end{array}$} & \multirow{2}{*}{$\begin{array}{c}\text { Meat } \\
17(6.02 \%)\end{array}$} & \multirow{2}{*}{$\begin{array}{l}\text { Poultry } \\
3(1.1 \%)\end{array}$} & \multirow{2}{*}{$\begin{array}{c}\text { Dairy } \\
11(3.9 \%) \\
\end{array}$} & \multirow{2}{*}{$\begin{array}{l}\text { Sea food } \\
18(6.4 \%) \\
\end{array}$} \\
\hline & & & & & & & & & & \\
\hline Amoxicillin/Calvulanic Acid (AMC/ 30) & 141 & 50 & 4 & 52 & 36 & 27 & 11 & 1 & 2 & 8 \\
\hline Ampicillin (AM/ 10) & 211 & 75 & 39 & 55 & 47 & 36 & 15 & 3 & 6 & 10 \\
\hline Cefazolin (CZ/ 30) & 156 & 55.1 & 21 & 49 & 33 & 32 & 9 & & 1 & 11 \\
\hline Ciprofloxacin (CIP/5) & 148 & 52.1 & 13 & 53 & 45 & 20 & 6 & 1 & 6 & 11 \\
\hline Clindamycin (DA/2) & 161 & 57 & 25 & 51 & 45 & 24 & 9 & 1 & & 6 \\
\hline Erythromycin (E/ 15) & 161 & 60 & 27 & 43 & 45 & 30 & 13 & 1 & 7 & 3 \\
\hline Gentamicin (CN /120) & 119 & 42 & 24 & 34 & 29 & 20 & 9 & & & 3 \\
\hline Imipenem (IPM/ 10) & 82 & 29 & 14 & 23 & 31 & 7 & 6 & & & 1 \\
\hline Nitrofurantion (F /300) & 101 & 36 & 27 & 23 & 16 & 23 & 4 & 2 & 3 & 3 \\
\hline Nitrofloxacin (NOR/ 10) & 118 & 42 & 23 & 45 & 33 & 9 & 4 & 2 & & 2 \\
\hline Penicillin (P/ 10) & 180 & 64 & 23 & 51 & 49 & 33 & 13 & & 1 & 10 \\
\hline Rifampin (RA/ 5) & 167 & 59 & 22 & 51 & 46 & 27 & 10 & 1 & & 10 \\
\hline Spectinomycin (SPT/100) & 113 & 40 & 31 & 25 & 31 & 16 & 6 & & & 4 \\
\hline Tetracycline (TE /30) & 141 & 50 & 32 & 35 & 42 & 22 & 4 & & & 6 \\
\hline Thiampinicol (TP/ 30) & 153 & 54 & 31 & 40 & 38 & 28 & 9 & & & 7 \\
\hline Vancomycin (VA /30) & 195 & 69 & 35 & 46 & 47 & 35 & 15 & 1 & 6 & 10 \\
\hline
\end{tabular}

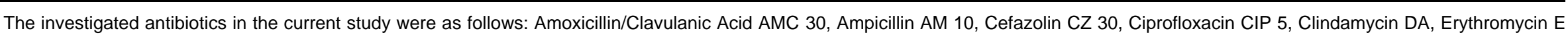

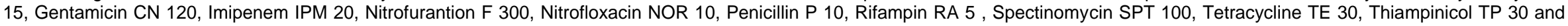
Vancomycin VA 30.

phenotype. Different intensities in the dye uptake were scored as $(+),(++)$ or $(+++)$, while appearance of white colonies ( $E$. coli which did not uptake the dye) indicates a Congo red negative (CR-) phenotype.

\section{Enteroheamolysin production}

Detection of hemolysin producers was performed according to the method described elsewhere (Blanco et al., 1997). Briefly, individual $E$. coli colonies were grown at $37^{\circ} \mathrm{C}$ for $24 \mathrm{~h}$ on tryptose blood agar (Difco) supplemented with $10 \mathrm{mM} \mathrm{CaCl}_{2}$ and $5 \%$ defibrinated washed sheep blood in phosphate saline. Positive $\beta$-hemolytic reactions were indicated by complete clear zones under and around

\section{the colonies.}

\section{Detection of virulence genes}

\section{Genomic DNA}

Purified genomic bacterial DNA was extracted, from overnight cultures of $E$. coli isolates after growth on TSA medium using genomic DNA mini kit (QIAGEN, QIAamp® USA) according to the manufacturer's instructions.

The DNA templates of 283 isolates were subjected to $\mathrm{mPCR}$ for screening of virulence genes using specific primers as described elsewhere (Table 2). Positive controls included DNA lysate prepared from clinical specimens positive for shiga toxins eae and hlyA which are kindly, provided by US Naval Medical Research Unit \#3 (NAMRU3) laboratories, Cairo-Egypt. The production of enterohemolysin was assayed on $75 \mathrm{E}$. coli isolates which demonstrated a beta hemolytic phenotype. The eae gene was only assayed using DNA obtained from shiga-toxin producing strains isolates. PCRs for detection of $s t \times 1$, st $\times 2$, eae, and hlyA genes were performed with commercially manufactured oligonucleotide primers. The primers used and the predicted lengths of PCR amplification products are listed in Table 2. These primers were chosen because they amplify conserved regions of the target genes and allow singlestep identification of amplified DNA fragments that are visualized as stained bands after migration on agarose gel electrophoresis. PCRs were performed in $25 \mu \mathrm{l}$ reaction 
Table 2. Primer sequences of examined virulence genes and predicted lengths of PCR amplification products (Fermentas International Inc. Burlington, Ontario,Canada).

\begin{tabular}{|c|c|c|c|}
\hline $\begin{array}{l}\text { Target } \\
\text { gene }\end{array}$ & $\begin{array}{l}\text { Oligonucleotide sequence } \\
\left(5^{\prime}-3^{\prime}\right)\end{array}$ & $\begin{array}{l}\text { Product length } \\
\text { (bases) }\end{array}$ & Cycle condition \\
\hline stx & $\begin{array}{l}\text { F -CAACACTGGATGATCTCAG } \\
\text { R-CCCCCTCAACTGCTAATA }\end{array}$ & $349 \mathrm{bp}$ & $\begin{array}{l}96^{\circ} \mathrm{C} 5 \min , 95^{\circ} \mathrm{C} 1 \mathrm{~min}, 55^{\circ} \mathrm{C} 1 \mathrm{~min}, 72^{\circ} \mathrm{C} 1 \mathrm{~min} \text { for } 30 \\
\text { cycles, } 72^{\circ} \mathrm{C} 7 \mathrm{~min}\end{array}$ \\
\hline stx & $\begin{array}{l}\text { F-ATCAGTCGTCACTCACTGGT } \\
\text { RCTGCTGCTGTCACAGTGACAAA }\end{array}$ & $110 \mathrm{bp}$ & $\begin{array}{l}96^{\circ} \mathrm{C} 5 \mathrm{~min}, 95^{\circ} \mathrm{C} 1 \mathrm{~min}, 55^{\circ} \mathrm{C} 1 \mathrm{~min}, 72^{\circ} \mathrm{C} 1 \mathrm{~min} \text { for } 30 \\
\text { cycles, } 72^{\circ} \mathrm{C} 7 \mathrm{~min}\end{array}$ \\
\hline hly & $\begin{array}{l}\text { F-ACGATGTGGTTTATTCTGGA } \\
\text { R-CTTCACGTGACCATACATAT }\end{array}$ & $165 \mathrm{bp}$ & $\begin{array}{l}96^{\circ} \mathrm{C} 5 \mathrm{~min}, 95^{\circ} \mathrm{C} 1 \mathrm{~min}, 48^{\circ} \mathrm{C} 1 \mathrm{~min}, 72^{\circ} \mathrm{C} 1 \mathrm{~min} \text { for } 30 \\
\text { cycles, } 72^{\circ} \mathrm{C} 7 \mathrm{~min}\end{array}$ \\
\hline eae & $\begin{array}{l}\text { F-GTGGCGAATACTGGCGAGACT } \\
\text { R-CCCCATTCTTTTTCACCGTCG }\end{array}$ & $890 \mathrm{bp}$ & $\begin{array}{l}96^{\circ} \mathrm{C} 5 \mathrm{~min}, 95^{\circ} \mathrm{C} 1 \mathrm{~min}, 55^{\circ} \mathrm{C} 1 \mathrm{~min}, 72^{\circ} \mathrm{C} 1 \mathrm{~min} \text { for } 30 \\
\text { cycles, } 72^{\circ} \mathrm{C} 7 \mathrm{~min}\end{array}$ \\
\hline
\end{tabular}

stx1:shiga toxin 1, stx2:shiga toxin 2, hlyA:enterohemolysin, eae: intimin

mixtures containing $2 \mu \mathrm{l}$ of template DNA, $5 \mu \mathrm{l}$ of $5 \times$ PCR buffer, 4 $\mu \mathrm{l}$ of a $2.5 \mathrm{mM}$ mixture of deoxynucleoside triphosphates, $2 \mu \mathrm{l}$ of 25 $\mathrm{mM} \mathrm{MgCl} 2,0.25 \mu \mathrm{l}$ of $5 \mathrm{U}$ of Ampli Taq Gold DNA polymerase per $\mu \mathrm{l}$, and $2 \mu \mathrm{l}$ of a $20 \mu \mathrm{M}$ concentration of each primer. The thermocycling conditions were done in a Gene Amp PCR system 9700 (AB Applied Biosystems). PCR products $(5 \mu \mathrm{l})$ were loaded onto $2 \%$ agarose gels and run at $120 \mathrm{mV}$ for $30 \mathrm{~min}$. A molecular marker (1kb DNA ladder; Gibco/BRL) was run concurrently. The DNA bands were visualized and photographed under UV light after the gel was stained with ethidium bromide.

\section{Serotyping}

Serotyping for the somatic "O" antigen of E.coli isolates propagated on 18-hour Nutrient broth cultures at $37^{\circ} \mathrm{C}$ was performed commercially in the Clinical Microbiology Reference Unit-Central Health Laboratories (Abdien Cairo, Egypt). A slide agglutination test (Koneman et al., 1999) was used employing 8 diagnostic polyvalent and 43 corresponding monovalent anti-E. coli sera provided by Denka Seiken, Chuo-ku/ Japan.

\section{RESULTS}

\section{Prevalence}

A total of $283 \mathrm{E}$. coli isolates were recovered from 384 samples collected from different sources in Ismailia. The prevalence of $E$. coli among the different sources is demonstrated in Table 3. E. coli was isolated with higher frequency from human stools $(31.4 \%)$, surface water $(17.3 \%)$, animal stools (17.3\%), human urine (16.5\%), seafood products $(6.4 \%)$ and processed meat products $(6.1 \%)$, while a lesser frequency was found from dairy products $(3.9 \%)$ and poultry products $(1.1 \%)$. Almost $70 \%$ $(n=194)$ of the $E$. coli isolates demonstrated clear invasive phenotype on CR agar while $26 \% \quad(n=75)$ showed beta-hemolytic patterns on blood agar. The invasive pattern phenotype was in isolates from diarrheic animals $(86 \%)$, seafood $(83 \%)$ meat products $(82 \%)$, urinary tract infection (UTI) $(77 \%)$ and diarrheic patients $(73 \%)$. In addition, high percentages of beta hemolytic phenotype were recorded in $E$. coli isolates originating from food products: poultry (66\%), processed meat $(47 \%)$ and seafood (33\%). Twenty two percent $(61 / 269)$ of isolates shared a common phenotype with respect to the presence of both invasive pattern on CR and $\beta$-hemolytic activity. Of these 61 isolates, 14 originated from human stool, 16 from animal stool, 13 from UTI, 6 from water, 10 from meat products, 1 from poultry and 1 from seafood. Most of the $E$. coli isolates with combined $\mathrm{CR}$ and $\beta$ hemolytic phenotype characteristics originated from clinical samples from patients with diarrhea and urinary tract infection.

\section{Antibiotic resistance phenotype}

The antibiotic resistance patterns of the $283 \mathrm{E}$. coli isolates are shown in Table 1. The results demonstrated that $75 \%$ of the isolates were resistant to $\mathrm{AM} / 10,69 \%$ to VA $/ 30,64 \%$ to $P / 10$ and $60 \%$ to E/ 15 . Almost $50 \%$ of the tested isolates were $\mathrm{AMC} / 30$ resistant. Fewer isolates were found to be resistant to NOR/ $10(36 \%)$ and IPM/10 (28\%). The antibiogram profile of $E$ coli strains carrying different virulence genes is demonstrated in Table 4. Most strains demonstrated multi-drug resistance index (MDRI), that is, they were resistant to at least four antibiotics belonging to different classes: E 15, CN 120, CZ 30, TP 30, VA 30, CIP5 and AM10. Strains belonging to the 0157 serogroup were sensitive to CIP and NOR, whereas $30 \%$ of strains belonging to non-O157 serogroups were resistant to CIP and 100\% were resistant to at least three antibiotics.

\section{Virulence genes}

Ten (10) shiga toxin producing strains were identified by mPCR. Three of these (EC255:O157, EC306:0158, EC322:0114) were positive for both $s t \times 1$ and stx2 while the remaining 7 isolates (EC150:0125, EC0111:O26, EC294:0158, EC357:0114, EC291:O26, EC158:0158, EC94:0157) were found positive only for stx1 (Table 4). 
Table 3. E coli isolates by source, hemolytic activity, Congo red indicator phenotype, and virulence genes.

\begin{tabular}{|c|c|c|c|c|c|c|c|c|c|c|}
\hline \multirow[b]{2}{*}{ Source } & \multirow{2}{*}{$\begin{array}{l}\text { Sample } \\
\text { type }\end{array}$} & \multirow{2}{*}{$\begin{array}{c}\text { Number of } \\
\text { samples } \\
(\mathrm{N}=384)\end{array}$} & \multirow{2}{*}{$\begin{array}{c}\text { Isolated } \\
\text { E. coli } \\
(\mathrm{N}=283)\end{array}$} & \multirow{2}{*}{$\begin{array}{c}\text { Prevalence } \\
\text { of } E \text {. coli } \\
(\%)\end{array}$} & \multirow{2}{*}{$\begin{array}{c}\text { Beta } \\
\text { hemolysis } \\
(\mathrm{N}=75)\end{array}$} & \multirow{2}{*}{$\begin{array}{l}\text { Congo red } \\
\text { indicator } \\
(\mathrm{N}=194)\end{array}$} & \multicolumn{4}{|c|}{ Virulence genes } \\
\hline & & & & & & & $\begin{array}{l}\text { stx1 } \\
\text { hlyA }\end{array}$ & $\begin{array}{c}\text { stx } 1 \\
/ 2\end{array}$ & $\begin{array}{r}\text { stx1 } \\
+ \text { +eae } \\
\end{array}$ & $\begin{array}{c}s t \times 1 / 2+ \\
\text { hly }\end{array}$ \\
\hline Surface water & $\begin{array}{l}\text { Fresh } \\
\text { canals }\end{array}$ & 31 & 49 & 17.3 & $7(14.2) \%$ & $19(39) \%$ & & & 1 & \\
\hline \multirow{3}{*}{ Human stool } & Male & 37 & 38 & 13.41 & $5(13) \%$ & $27(71 \%)$ & & & & \\
\hline & Female & 27 & 20 & 7.1 & $8(40 \%)$ & $19(95 \%)$ & & & & \\
\hline & Children & 43 & 31 & 10.92 & $7(22.5 \%)$ & $19(61.2 \%)$ & 1 & & & \\
\hline \multirow{2}{*}{ Human urine } & Male & 24 & 8 & 2.82 & $5(62.5 \%)$ & $8(100 \%)$ & 1 & & & \\
\hline & Female & 52 & 39 & 13.7 & $9(23 \%)$ & $28(71 \%)$ & 1 & & & 1 \\
\hline \multirow{4}{*}{ Animal stool } & Cattle & 33 & 14 & 4.9 & $5(35.7 \%)$ & $14(100 \%)$ & & & 1 & \\
\hline & Calves & 20 & 5 & 1.78 & $2(40 \%)$ & $3(60 \%)$ & 1 & & & \\
\hline & Sheep & 9 & 20 & 7.1 & $5(25 \%)$ & $15(75 \%)$ & & 1 & & \\
\hline & Chickens & 9 & 10 & 3.55 & $4(40 \%)$ & $10(100 \%)$ & 1 & & 1 & \\
\hline \multirow{7}{*}{ Meat products } & Minced & 11 & 3 & 1.1 & $3(100 \%)$ & $2(66.6 \%)$ & & & & \\
\hline & Steaks & 3 & 6 & 2.12 & $1(16.6 \%)$ & $6(100 \%)$ & & & & \\
\hline & Sausage & 8 & 2 & 0.7 & $2(100 \%)$ & $1(50 \%)$ & 1 & & & \\
\hline & Kofta & 6 & 2 & 0.7 & $1(50 \%)$ & $2(100 \%)$ & & 1 & & \\
\hline & Burger & 8 & 0 & 0 & 0 & 0 & & & & \\
\hline & Luncheon & 8 & 4 & 1.4 & $1(25 \%)$ & $3(75 \%)$ & & & & \\
\hline & Liver & 4 & 0 & 0 & 0 & 0 & & & & \\
\hline \multirow{3}{*}{$\begin{array}{l}\text { Poultry } \\
\text { products }\end{array}$} & Livers & 6 & 3 & 1.1 & $2(66 \%)$ & 2 (66.6\%) & & & & \\
\hline & Lamps & 8 & 0 & 0 & 0 & 0 & & & & \\
\hline & Oysters & 9 & 7 & 2.5 & 2 (28.5\%) & $6(85.7 \%)$ & & & & \\
\hline \multirow[t]{2}{*}{ Sea food } & Calamari & 7 & 4 & 1.4 & 2 (28.5\%) & $4(100 \%)$ & & & & \\
\hline & Bivalves & 7 & 7 & 2.5 & $2(28.5 \%)$ & 5 (71.4\%) & & & & \\
\hline \multirow{3}{*}{ Dairy products } & Raw milk & 6 & 4 & 1.4 & $1(25 \%)$ & $1(25 \%)$ & & & & \\
\hline & Yogurt & 4 & 4 & 1.4 & 0 & 0 & & & & \\
\hline & Cheese & 4 & 3 & 1.1 & $1(33 \%)$ & 0 & & & & \\
\hline Total & & 384 & 283 & & & & & & & \\
\hline
\end{tabular}

Congo red (CR) binding activity indicated that $194 \mathrm{E}$. coli isolates (70\%) shown clear invasive phenotype on CR agar while 75 isolates $(26.6 \%)$ shown beta hemolytic phenotype in blood agar. Twenty two percent $(61 / 269)$ of isolates shared a common phenotype with respect to the presence of both invasive pattern on CR agar and $\beta$-hemolytic activity. Of these 61 isolates, 14 originated from human stool, 16 from animal stool, 13 from UTI , six from surface water, 10 from meat products, one from poultry and 1 from sea food.

The 10 shiga toxin producing strains were tested for the presence of the eae virulence gene, as an indicator of intestinal invasion. Three shiga toxin producing strains were positive for the eae gene with a 890-bp PCR product. In addition, PCR testing of the 75 beta hemolytic E. coli isolates yielded three hlyA-positive strains with a PCR product of 165 -bp.

\section{Serotyping}

Serotyping of the ten STEC strains revealed five serotypes (O157, O158, O114, O125 and O26) (Table 4): three human isolates (serotypes 0157, 0158), four animal isolates (serotypes 0114, O26), two isolates from meat products (serotypes 0125, O158) and one isolate from water (serotypes 0114). Three STEC strains, belonging to three serotypes, were positive for both stx 1 and stx2. These strains were isolated from a urine sample of a female with urinary tract infection (serotypes O157), a stool sample from infected sheep (serotypes O114) and from a meat product (serotypes 0158).

\section{DISCUSSION}

STEC can cause diarrhea, bloody diarrhea and hemorrhagic colitis in humans. STEC infections also frequently result in hemolytic-uremic syndrome (HUS), a lifethreatening condition characterized by hemolytic anemia, thrombocytopenia and renal failure (Tarr et al., 2005). Transmission of STEC occurs through contaminated foods, such as ground beef, through contaminated water and by person-to-person spread (Steinmuller et al., 2006).

In some countries, $\mathrm{O} 157: \mathrm{H} 7$ is the most common serotype of STEC (Gould, 2009) and is the serotype most often associated with HUS (Voetsch et al., 2004). Approximately 150 non-O157 STEC serotypes also cause diarrheal disease (European Food Safety Authority, 2010). Some studies suggest that non-O157 STEC infections result in milder disease compared to O157 infections (Brooks et al., 2005). Most of the medically significant reports on O157 STEC are published in developed countries, and only a handful of reports are 
Table 4. Antibiogram, serotypes and origin of STEC strains by genetic and phenotypic characteristics

\begin{tabular}{|c|c|c|c|c|c|}
\hline $\begin{array}{l}\text { Isolate } \\
\text { origin }\end{array}$ & $\begin{array}{l}\text { Positive } \\
\text { genes }\end{array}$ & Serotype & $\begin{array}{l}\text { Resistance } \\
\text { Profile }\end{array}$ & $\begin{array}{l}\text { Non-resistance } \\
\text { profile }\end{array}$ & $\begin{array}{l}\text { Multi-drug resistance } \\
\text { index MDRI (\%) }\end{array}$ \\
\hline $\begin{array}{l}\text { EC94: } \\
\text { Child stool }\end{array}$ & Stx 1 & 0157 & $\begin{array}{l}\text { Am 10, P 10, SPT, } \\
\text { AMC 30, IPM 20, } \\
\text { CN 120, CZ 30, } \\
\text { VA } 30\end{array}$ & $\begin{array}{l}\text { F } 300, \text { TE } 30, \\
\text { CIP 5, NOR 10- } \\
\text { TP } 30 \text { DA } 2,\end{array}$ & 50 \\
\hline $\begin{array}{l}\text { EC306: Meat } \\
\text { Kofta) }\end{array}$ & $\begin{array}{l}\text { Stx } 1 \\
\text { Stx2 }\end{array}$ & O158 & $\begin{array}{l}\text { Am 10, E 15, P 10, } \\
\text { TE 30, RA 5, DA 2, } \\
\text { AMC 30, IPM 20, } \\
\text { CN 120, NOR 10, } \\
\text { CZ 30, TP 30, VA } \\
30\end{array}$ & CIP 5 & 81.25 \\
\hline $\begin{array}{l}\text { EC294: } \\
\text { Calf stool }\end{array}$ & Stx 1 & 0158 & $\begin{array}{l}\text { Am10, E15, P10, } \\
\text { SPT, F 300, TE } \\
30, \text { CIP } 5, \text { TP } 30\end{array}$ & $\begin{array}{l}\text { RA 5, DA } 2, \\
\text { AMC } 30, \quad \text { CN } \\
120, \text { NOR } 10, \\
\text { CZ } 30\end{array}$ & 50 \\
\hline $\begin{array}{l}\text { EC158: } \\
\text { (Male) }\end{array}$ & Stx 1 & O158 & $\begin{array}{l}\text { Am 10, E } 15, \text { P } 10, \\
\text { TE 30, RA 5, DA 2, } \\
\text { AMC 30, CN 120, } \\
\text { CIP 5, NOR 10, } \\
\text { CZ 30, TP } 30, \text { VA } \\
30\end{array}$ & $\begin{array}{l}\text { SPT, F 300, IPM } \\
20, \text { RA } 5\end{array}$ & 81.25 \\
\hline $\begin{array}{l}\text { EC322: } \\
\text { Sheep (stool) }\end{array}$ & $\begin{array}{ll}\text { Stx } & 1 \\
\text { Stx2 } & \end{array}$ & 0114 & $\begin{array}{l}\text { E 15, SPT, F 300, } \\
\text { TE 30, IPM 20, CN } \\
120, \text { CIP } 5, \\
\text { NOR10, TP } 30, \text { VA } \\
30\end{array}$ & $\begin{array}{l}\text { Am 10, RA 5, DA } \\
2, \text { AMC } 30\end{array}$ & 56.25 \\
\hline $\begin{array}{l}\text { EC357: } \\
\text { Raw water }\end{array}$ & $\begin{array}{l}\text { Stx } 1 \\
\text { eae }\end{array}$ & 0114 & $\begin{array}{l}\text { Am10, E15, SPT, } \\
\text { F 300, TE } 30, \text { RA } \\
5, \text { DA 2, CN 120, } \\
\text { TP } 30, \text { VA } 30\end{array}$ & CIP 5, NOR 10 & 62.5 \\
\hline $\begin{array}{l}\text { EC150: } \\
\text { Meat (sausage) }\end{array}$ & Stx 1 & 0125 & $\begin{array}{l}\text { Am 10, E 15, P 10, } \\
\text { TE 30, RA 5, DA 2, } \\
\text { CN 120, NOR 10, } \\
\text { CZ 30, TP 30,VA } \\
30\end{array}$ & $\begin{array}{l}\text { IPM 20, SPT , } \\
\text { F300 }\end{array}$ & 68.75 \\
\hline $\begin{array}{l}\text { EC0111: } \\
\text { Chicken (stool) }\end{array}$ & $\begin{array}{l}\text { Stx } 1 \\
\text { eae }\end{array}$ & O26 & $\begin{array}{l}\text { Am10, E15, P10, } \\
\text { SPT, F300 TE 30, } \\
\text { RA 5, DA 2, AMC } \\
30, \text { CIP } 5\end{array}$ & $\begin{array}{l}\text { IPM 20, TP } 30, \\
\text { VA } 30\end{array}$ & 62.5 \\
\hline $\begin{array}{l}\text { EC291: } \\
\text { Cattle (stool) }\end{array}$ & $\begin{array}{l}\text { Stx } 1 \\
\text { eae }\end{array}$ & $\mathrm{O} 26$ & $\begin{array}{l}\text { Am 10, SPT, CN } \\
120, \text { VA } 30\end{array}$ & $\begin{array}{l}\text { E 15, F 300, RA } \\
5, \text { DA 2, AMC } \\
30, \text { IPM 20, NOR } \\
\text { 10, CZ 30, TP } 30\end{array}$ & 25 \\
\hline
\end{tabular}

available from developing countries with nearly no data available on non-O157 STEC from countries in North Africa and the Middle East. The aims of the present study were to identify the frequencies of $\mathrm{O} 157$ and non-O157 STEC among different human, animal and environmental sources and to characterize the genetic background and 
virulence traits of suspected STEC isolates.

In the current study, $283 \mathrm{E}$. coli isolates were recovered from 384 samples collected from different sources in Ismailia, one of the largest governorates located in the North-east of Egypt, on the West Bank of the Suez canal. The highest isolation frequencies of $E$. coli among the different sources were from human stool (31.4\%), surface water and animal stools (17.3\%), human urine (16.5\%), and processed meat products $(6.1 \%)$, with lower isolation frequencies from dairy products $(3.9 \%)$ and poultry products $(1.1 \%)$. The current study assayed for the presence of virulence genes in the $283 \mathrm{E}$. coli isolates and for their in vitro invasive properties. Findings showed that $70 \%$ of the isolates demonstrated an invasive phenotype on CR agar while $26 \%$ displayed betahemolytic patterns on blood agar. These percentages were similar to those obtained by other groups (Abhilasha et al., 2001; Hussin 1998; Sahaly, 1995) who found that profiles positive for the Congo red test and hemolysis were widely spread among $E$. coli strains isolated from diseased animals. In the current study, most positive CR and $\mathrm{EHL}$ isolates were obtained from clinical samples from patients with diarrhea and urinary tract infections, indicating the potential of these isolates to cause disease. This corroborates with previous findings (Hoda, 2009) that emphasized the role of hemolysin-producing $E$. coli in the increase of pathogenic potential and the critical role these organisms play in causing extra-intestinal infection. An invasive pattern phenotype was recorded in isolates from a considerably high percentage of diarrheic animals $(86 \%)$, seafood $(83 \%)$, meat products $(82 \%)$, UTI $(77 \%)$ and diarrheic patients (73\%), whereas the beta hemolytic phenotype was widely spread among isolates originating from diverse food products $(66 \%$ from poultry, $47 \%$ from processed meat and 33\% from seafood). These highly prevalent virulence phenotypes may reflect that the majority of the isolated $E$. coli possess the potential to cause disease.

The antibiotic resistance profile of the 283 E. coli isolates indicated that antibiotic resistance is quite common among the $E$. coli isolates: $75 \%$ of the isolates were resistant to AM followed by VA (69\%), P (64\%), E $(60 \%)$, while $55 \%$ demonstrated resistance to CIP and $50 \%$ resistance to tetracycline. In addition, $50 \%$ of the tested isolates were resistant to AMC which was mainly isolated from human stool $(n=52)$, animal stool $(n=36)$, UTI $(n=27)$, meat products $(n=11)$, seafood $(n=8)$, water $(n=2)$, dairy products $(n=2)$ and poultry $(n=1)$. Almost $93 \%$ of the isolated E. coli were MDR as they were resistant to between 4 and 13 of the tested antibiotics; this pattern was more pronounced among isolates from clinical samples and meat products as all of these isolates were resistant to $\mathrm{AMC} / 30, \mathrm{AM} / 10, \mathrm{E} / 15$, $\mathrm{P} / 10, \mathrm{RA} / 5$, TE /30 and VA /30. The MDR phenotypes among clinical samples represent a major health threat and suggest that some of these drugs may be of limited use. The detection of EHEC poses a challenge for clinical microbiology laboratories. Key issues concerning their detection include the need to distinguish from commensal E. coli (Bennett-Wood et al., 2004, Edson et al., 2010). The currently accepted method for detection may be direct plating on SMAC or other media such as cefeximeSMAC or SMAC supplemented with cefexime and tellurite (CT-SMAC). Culture on SMAC is a simple method for screening for STEC O157, but it cannot identify non-O157 serogroups. The multiplex PCR approach for the detection of stx1, stx2, eaeA and hlyA genes is advantageous in rapidly detecting these virulence genes and is highly recommended.

Our study demonstrates that non-O157 STEC comprised a significant proportion (70\%) of all STEC strains detected. SMAC culture was selected for detection of STEC in which 10 STEC strains primarily appeared as typical E. coli colonies (pink-red), and could not be differentiated from other pathogenic or non-pathogenic (commensal) E. coli strains which grow on the same medium. We applied PCR assay for shiga toxins detection and found the assay to be a helpful tool for the detection of STEC belonging to both $\mathrm{O} 157$ and non-O157 serogroups. Our data support the consideration of others in the mandated use of a Shiga toxin assay for the identification of STEC (Kehl, 2002). If only a Shiga toxin assay is used, it is important that positive samples be subcultured for STEC detection and serotyped, with the goal of identifying and curtailing potential outbreaks of STEC infection. We were able to identify molecular markers (stx 1 , stx 2 and $h l y A)$ for the 10 STEC isolates which represented $4 \%$ of the total isolates. Three strains carried both stx 1 and st $x 2$, seven strains carried stx 1 only, one strain carried stx 1 , stx 2 and $h / y A$ and three strains carried stx 1 and eae $A$.

It was of a particular concern to find that all the 10 STECs belonging to both $\mathrm{O} 157$ and non-O157 serogroups were positive for both $\mathrm{CR}$ and hemolysis tests, indicating that these serogroups may share common virulence characteristics. Most studies on 0157 and non-O157 STEC have included mixed populations of adults and children (Brooks et al., 2005; CDC, 2005). Outbreaks of non-O157 STEC have been reported in children (Ethelberg, 2007) and in 38\% of STEC infections among a pediatric cohort (Klein et al., 2002). Our results identified seven STEC strains that were isolated from clinical samples, of which four were isolated from stools of diarrheic animals and two (O157and non-O157) were from adult patients with UTIs and one (O157) was from stool of diarrheic child under 5 years of age. Data collected from multiple sites in the world showed that the highest incidence of both E. coli O157 infection and HUS occurred among children of up to 5 years old and that the median age of patients with HUS was 4 years (Gould, 2009); nevertheless, the incidence of non-0157 STEC infection and the clinical sequelae need to be more clearly defined (Klein et al., 2002). E. coli accounted for the majority of urinary tract infections in young adults and 
pregnant women (Joshua et al., 2006).EHEC can cause hemolytic colitis (Johnson et al., 2006), and hemolytic uremic syndrome (HUS) which progress in some patients to renal failure (Kooopman et al., 1991). HUS is a life threatening condition especially among children and the elderly (Kooopman et al., 1991). In Nigeria, Akinduti et al. (2008) isolated O157:H7 serotype from urine samples of adult males and females suffering from severe UTI. Akinduti et al. (2008) reported a very high prevalence (46.4\%) of E. coli 0157:H7 among tested patients; their study cited that renal diseases associated with severe UTI were mainly caused by E. coli O157:H7. The percentage of STEC in our clinical UTI samples is considered notably high considering the small number of UTI cases $(n=47)$ included in the study. To the best of our knowledge, this report is the first from the country to identify non-O157 STEC from patients with UTI, which suggests the need for further community and hospitalbased surveillance studies to better estimate the prevalence of STEC in this region and their impact on human disease.

Christina et al. (2011) surveyed 5,110 children for STEC at Children's Hospital in Boston and demonstrated that 50 cases $(0.9 \%)$ had confirmed STEC infections; 33 were caused by $\mathrm{O} 157: \mathrm{H} 7$ strains and 17 were caused by non-O157:H7 strains belonging to various serotypes such as O25: $\mathrm{H} 11, \mathrm{O} 26: \mathrm{H} 11, \mathrm{O} 26: \mathrm{H} 28, \mathrm{O} 111$ :nonmotile, O118:H16, O126:H1, O130:H11, O145:nonmotile and O146:H28. However, there were no significant differrences in disease severity between STEC infections in children caused by $\mathrm{O} 157: \mathrm{H} 7$ and those caused by nonO157 STEC. Our survey identified a comparable percentage in the distribution of non-0157 serogroups as those reported from Christina et al. (2011) as we identified four non-O157 serogroups (O158, O114, O125 and O26) which were isolated from clinical specimens, meat products and water.

The MDR phenotype of both 0157 and non-O157 strains in the current study signifies that the specific STEC isolates are highly resistant to commonly available antibiotics, limiting the selection of treatment choice. Multidrug resistance among $E$. coli isolates has been a subject of concern worldwide (Chitnis et al., 2003, Lestari et al., 2008). Ground beef and other bovine products have often been implicated as sources of Shiga toxigenic E. coli (Griffin and Tauxe, 1991), along with other food products (Ackers et al., 1998). Occasional outbreaks of STEC have also been associated with drinking public water (Swerdlow et al., 1992) and swimming in contaminated water (Friedman et al., 1999).

The present investigation also revealed three nonO157 STEC strains, two originating from processed meat products and one from the main fresh water canal of Ismailia. It was unknown whether the contamination of meat or water originated from animal or human sources but conceivably, a combination of the above origins could explain the presence of STEC traits found in these isolates.
We are in the process of analyzing PFGE results of all STEC strains to compare clonality and evaluate the relatedness of the isolated strains. Most of the STEC isolates in our study possess two or more virulence factors or traits (CR indicator, hemolysin production, st $x$, $s t x 2, h(y A)$. The presence of multiple virulence factors increases the virulence potential of microorganisms, since such factors function synergistically to overcome and defeat normal host defences. Thus, strains with more virulence factors are potentially considered as virulent pathogens (Hamuel et al., 2011). Our findings may imply that the isolates from the examined sources could be considered as potentially pathogenic.

It is of interest to demonstrate that STEC serotype O104 was not identified from the environmental sources tested in the present study; fenugreek imported from Egypt during the period 2009 to 2011 was blammed as the most likely source of STEC epidemic in Germany that resulted in 49 deaths. One of the limitations of this investtigation is that we could not identify the $(\mathrm{H})$ flagellar antigens and hence determine the exact serotype for the isolated shiga toxin producing $E$. coli as it was commercially unavailable during the time-frame of our study. Additionally, since this is considered as a lab-based study, and with the small number of human disease cases in the present study (and the lack of clini-cal data), an association between disease severity and specific STEC serotypes could not be made.

\section{REFERENCES}

Abhilasha SSP, Gupta RS (2001). Pathogenicity and in vivo drug resistance in chicks of Tarai region. Ind. J. Comp. Microbiol. Immun. Inf. Dis. 22(2):166-167.

Abong'o BO, Momba MNB (2009). Prevalence and characterization of Escherichia coli $0157: \mathrm{H} 7$ isolates from meat and meat products soldin A mathole District, Eastern Cape Province of South Africa. Int. J. Food Microbiol. 26:173-176.

Ackers ML, Mahon BE, Leahy E, Goode B, Damrow T, Hayes PS, Bibb WF, Rice DH, Barrett TJ, Hutwagner L, Griffin PM, Slutsker L (1998). An outbreak of Escherichia coli O157:H7 infections associated with leaf lettuce consumption. Infect. Dis. 177:1588-1593.

Akinduti PA, Akinbo JA, Ejilude OA, Mannie-Udoh MI, Umahoin KO, Ogunbileje JO, Folarin BO (2008). Prevalence Of Enterohaemorrhagic Eschericia coli 0157:H7 Causing Severe Urinary Tract Infection In Abeokuta, Nigeria. American Science 4:1545-1003.

APHA (1998). Standard methods for the examination of water and waste water. American Public Health Association Washington D.C. 19th ed.

Bennett-Wood VR, Russell J, Bordun AM et al (2004). Detection of enterohaemorrhagic Escherichia coli in patients attending hospital in Melbourne, Australia. Pathology. 36(4):345-351.

Berkhoff HA, Vinal AC (1986). Congo red medium to distinguish between invasive and non invasive $E$. coli pathogenic for poultry Avian. Dis. 30(1):117-121.

Bettelheim KA (1996) Enterohaemorrhagic Escherichia coli. A review. Int. Food Hyg. 7:5-9.

Blanco, Blanco JE, Mora MA, Blanco J (1997). Production of toxins (enterotoxins, verotoxins and necrotoxins) and colicins by $E$ coli strains isolated from septicaemic and healthy chickens: Relation with in vivo Pathogenicity. Ciln. Microbiol. 35(11):2953-2957.

Brooks JT et al (2005). Non-0157 Shiga toxin-producing Escherichia coli infections in the United States. 1983-2002. Infect. Dis. 192:1422- 
1429.

Centers for Disease Control (CDC, 2007). Laboratory-confirmed nonO157 Shigatoxin-producing Escherichia coli. Connecticut, 2000-2005. Morb. Mortal. Wkly. Rep. 56:29-31.

Centers for Disease Control and Prevention (CDC ,1999). Outbreak of E. coli O157:H7 and Campylobacter-New York. Morb. Mortal. Wkly Rep. 48:803-804.

Chandran A, Hatha AAM, Varghese S, Sheeja KM (2008). Prevalence of multidrug resistant $E$. coli serotypes in a Tropical Estuary, India. Microbes Environ. 23(2):153-158.

Chitnis SV, Chitris V, Sharma N, Chitnis DS (2003) Current status of drug resistance among gram negative bacilli isolated from admitted cases in a tertiary care centre. Assoc. Phys. India. 51:28-31.

Christina R, Hermos, Marcie J, Linda L, Han, Alexander J (2011). Shiga Toxin-Producing Escherichia coli in Children: Diagnosis and Clinical Manifestations of $\mathrm{O} 157: \mathrm{H} 7$ and Non-O157:H7 Infection. Clinical Microbiology. 49(3):955-959.

Clinical and Laboratory Standards Institute CLSI, (2003). Performance standards for antimicrobial susceptibility testing document. M100S14.,Wayne, PA.

Cowan ST (1985). Cowan and Steel's manual for identification of medical bacteria., Cambridge University Press, Cambridge, London 2nd ed. 138-139.

Dunn JR, Keen JE, Thompson RA (2004). Prevalence of Shigatoxigenic Escherichia coli O157:H7 in adult dairy cattle. Am. Vet. Med. Assoc. 224:1151-1158.

Edson CA, Glick T, Massey L (2010). Identification of Escherichia coli $\mathrm{O} 157: \mathrm{H} 7$ in a proficiency testing program: an update of laboratory performance. Lab. Med. 41:21-24.

Ethelberg S (2009). Outbreak of non-O157 Shiga toxin-producing Escherichia coli infection from consumption of beef sausage. Clin. Infect.Dis. 48:e78-e81.

European Food Safety Authority (2010). The community summary reporton trends and sources of zoonoses and zoonotic agents in the European Union in 2008. Eur. Food Saf. Auth. J. 10:1496.

Ezawa A, Gocho F, Kawata K, Takahashi T, Kikuchi N (2004). High prevalence of enterohemorrhagic Escherichia coli (EHEC) 0157 from cattle in selected regions of Japan. Vet. Med. Sci. 66:585-587.

Fagan PK, Hornitzky MA, Bettelheim KA, Djordjevic SP (1999). Detection of Shiga-like toxin (stx1 and stx2), intimin (eaeA), and Enterohemorrhagic Escherichia coli (EHEC) hemolysin (EHEC hlyA) genes in animal feces by multiplex PCR. Appl. Environ. Microbiol. 65:868-872.

Friedman MS, Roels T, Koehler JE, Feldman L, Bibb WF, Blake P (1999). Escherichia coli O157:H7 outbreak associated with an improperly chlorinated swimming pool. Clin. Infect. Dis. 29:298-303.

Gould LH (2009).Recommendations for diagnosis of Shiga toxin producing Escherichia coli infections by clinical laboratories. MMWR Recommend. Rep. 58:1-14.

Griffin PM, Tauxe RV (1991).The epidemiology of infections caused by Escherichia coli O157: $\mathrm{H7}$, other enterohemorrhagic E. coli, and the associated hemolytic uremic syndrome. Epidemiol. Rev. 13:60-98.

Hamuel JD, Patrick AN, Izanne SH, Spinney B (2011). Virulence factors and antibiotic susceptibility among verotoxic non O157: H7 Escherichia coli isolates obtained from water and wastewater samples in Cape Town, South Africa. Afr J. Biotechnol. 10(64):14160-14168.

Hoda ME (2009). Correlation between antigenic structure of $E$ coli and its virulence. Ph.D.Thesis (Microbiology) Fac. Vet. Med. Suez Canal Univ.

Hoffman SL (1993). Shiga-like toxins in hemolytic uremic syndrome and thrombotic thrombocytopenic purpura. JAMA 306:398-406.

Hussin AA (1998). Properties of E coli strains isolated from colisepticaemic rabbits and chickens. Ph.D. Thesis (Microbiology) Fac. Vet. Med. Suez Canal Univ.
Izenberg HD (2003). Urine Cultures, in Clinical Microbiology Procedures. Handbook, ASM Press, Washington, DC 2nd ed. Vol.1.

Jorgensen JH, Turnide JD, Washington JA (1997). Antibacterial Susceptibility Tests: Dilution and Disk Diffusion Methods. In: Manual of Clinical Micro-biology, ASM Press, Washington, DC 4th ed.

Joshua EN, Israel AJ, Edigba BA (2006). Prevalence of Escherichia coli O157:H7 from diarrhea patients in Jos hospital, Nigeria. Food, Agric Environ. 4:20-22.

Johnson JF, Kuskowski MA, Manard M, Gajewski A, Xercavins M, Garau J (2006). Similarity of human and chicken-source Escherichia coli isolates in relation to ciprofloxacin resistance status Infect. Dis. 194:71-78.

Karmali MA (1989). Infection by verocytotoxin-producing Escherichia coli. Clin. Microbiol. Rev. 2:5-38.

Kehl SC (2002). Role of the laboratory in the diagnosis of Enterohemorrhagic Escherichia coli infections. Clin. Microbiol. 40:2711-2715.

Klein EJ et al (2002). Shiga toxin-producing Escherichia coli in children with diarrhea: a prospective point-of-care study. Pediatr. 141:172177.

Koneman EW, Allen SD, Janda WM, Schreckenberger PC, Winn WC (1999). Color atlas and textbook of diagnostic microbiology. JB Lippincott company, Philadelphia, P.A. 4th Ed.

Kooopman JS, Louini, Jacquez JA, Simon CP (1991). Assessing risk factors for transmission of infection. Am. J. Epidemiol. 133:1199-1209

Louie M, de Azavedo JCS, Handelsman MYC, Clark CG, Ally B, Dytoc M, Sherman P, Brunton J (1993). Expression and characterization of the eaeA gene product of Escherichia coli serotype O157:H7. Infect. Immun. 61:4085-4092.

Lestari ES, Severin JA, Filius PMG, Kuntaman K, Duerink DO, Hadi U, Wahjono H, Verbrugh HA (2008). Antimicrobial resistance among commensal isolates of E.coli and S.aureus in the Indonesian population inside and outside hospitals. Eur. Clin. Microbiol. Infect. Dis. 27:45-51.

Merchant IA, Packer RA (1967).Veterinary Bacteriology and Virology. The lowa State University Press, Ames, lowa, USA. 7th ed. 211-305.

O'Brien AD, Holmes RK (1987). Shiga and Shiga-like toxins. Microbiol. Rev. 51:206-220.

Panigarhy B, Yushen L (1990). Differentiation of pathogenic and non pathogenic $E$ coli isolated from poultry. Avian Dis. 34:941-943.

Paton JC, Paton AW (1998). Pathogenesis and diagnosis of Shiga toxin producing Escherichia coli infections. Clin. Microbiol. Rev. Af. J. Biotechnol. 64(10):14160-14168, 11:450-479.

Sahaly ME (1995). Characterization of $E$. coli isolated from broiler. M.V.Sc. Thesis (Microbiology) Fac. Vet. Med. Alex. Univ.

Schmidt HB, Plaschke S, Franke H, Russman A, Schwarzkopf J, Heesemann, Karch H (1994). Differentiation in virulence patterns of Escherichia coli possessing eae genes. Med. Microbiol. Immunol. 183:23-31.

Steinmuller NL, Demma JB, Bender M, Eidson, Angulo FJ (2006). Outbreaks of enteric disease associated with animal contact: not just a foodborne problem anymore. Clin. Infect. Dis. 43:1596-1602.

Tarr PI, Gordon CA, Chandler WL (2005).Shiga-toxin-producing Escherichia coli and haemolytic uraemic syndrome. Lancet 365:10731086.

Voetsch AC et al (2004).Laboratory practices for stool-specimen culture for bacterial pathogens, including Escherichia coli $\mathrm{O} 157: \mathrm{H} 7$ in the FoodNet sites 1995-2000. Clin. Infect. Dis. 38(3):S190-S197. 